\title{
Translation of The King of Spain's Daughter (1935), by Teresa Deevy
}

\author{
Andrés Romera (Translation)
}

Copyright of the translation (C) 2020 by Andrés Romera. This text may be archived and redistributed both in electronic form and in hard copy, provided that the author and journal are properly cited and no fee is charged for access.

\section{The King of Spain's Daughter}

BY

TERESA DEEVY

THE KING OF SPAIN'S DAUGHTER was first produced on

April 29, 1935 in the Abbey Theatre, Dublin, with the following cast:

PETER KINSELLA.

JIM HARRIS

MRS MARKS

ANNIE KINSELLA

RODDY MANN
JOHN STEPHENSON

CYRIL CUSACK

ANN CLEARY

RIA MOONEY

J.WINTER

The play was produced by Fred Johnson

This transcription is created from manuscript $\mathrm{PP} / 6 / 97$ which is held in the Teresa Deevy Archive in Maynooth University.

The King of Spain's Daughter

A One-Act Play

Characters:

Peter Kinsella

Jim Harris

\section{Labourers}

ISSN 1699-311X 
Mrs. Marks

Annie Kinsella

Roddy Mann
A Neighbour

Peter's Daughter

A Loafer

The action of the play takes place on a grassy road in Ireland during the dinner-hour of a day in April.

\section{The King of Spain's Daughter}

SCENE - An open space on a grassy road. At each side road-barriers with notices "No Traffic" and "Road Closed". At the back an old dilapidated wall; a small door in the centre of the wall stands open and fields can be seen beyond. County Council workers have been employed here. Two coats, a thermos flask, an old sack and a man's hat and stick have been left on a pile of stones near one of the barriers. PETER KINSELLA, a heavily built man of fifty, comes through the doorway. He carries a pick axe, his overalls and boots are covered with a fine dust. He stands in the centre, looks away to the left, shading his eyes - then to the right. JIM HARRIS comes on, whistling. He is twenty-four, wears a cap and dusty overalls. He leaves his spade against the wall, goes to the barrier at the right side leans on it, looking away to the right.

JIM: Great work at the weddin' below. Miss What's-her-name getting married. The women were gathered at the wharf an hour and a half before time for send-off. (Laughs. PETER nods without interest). Right well it looked from above, with the white launch, an' the flags flyin' an' the sun on the water. Brave and gay at the start however 'twill go. (Takes his thermos flask). Come on, man. With the noise of the sirens I didn't hear the whistle, an' I kept workin' five minutes too long. Wasn't that a terrible thing to have happen to me?

PETER: She's late with my dinner.

JIM (dismayed): What? Didn't she come here at all?

PETER: She did not. Late - the second time in the week.

JIM: 'Tis on account of that weddin'. She'll be up now. They don't feel time or weather when they're waitin' for a bride.

PETER: I'll make her feel something ... her father without his dinner.

JIM (looking to the right): Is it at the wharf she is? or the far side of the river watchin' the start?

PETER: Do I, or anyone, ever know, where Annie'd be? Only sisters you have but they'd give you more thought than that daughter of mine. Oh, she'll be sorry yet. 
JIM: It is because of the day; the women can think of nothin' else; they're all the same. Molly and Dot were up at the dawn - would it be a fine day! You'd think they were guests invited. They know her by eye-sight so they'll go stand in the crowd and see how she'll look.

PETER: If I knew where to get Annie.

JIM: Annie'll be here now. They're scattering away off the wharf-though I can't pick her out.

PETER: And how would you? More than likely she's off with Roddy Mann. Philanderin' with the like of him - that's all she's fit for- or with any boy she can lay hold of.

JIM: If she goes on a bit aself 'tis because she must; she's made that way, she can't help it.

PETER: I'll make her help it! You're in no great hurry to have her.

JIM (flings round on him): You know that I am!

PETER: Why don't you marry her so? and stop her goin' on? You're in no hurry.

JIM: I want that, and you know it. How can I force the girl?

PETER: Ay, how indeed? (Laughs contemptuously). Aw, you're very young.

(Goes to the door, stands there looking out across the field. JIM sits down on the stones and begins his dinner. MRS. MARKS, a big woman of fifty-five or so, wearing a shawl and with a basket on her arm, comes to the barrier at the right. She pushes the barrier a little aside and comes on).

MRS. MARKS: Can I pass this way? 'Twould be a short cut.

JIM: Are you a motor car, ma'am? (Looks her up and down). You are not - 'tis two legs are under you. You can, and welcome.

MRS. MARKS: I thought you had sense in your head, Jim Harris. (Puts dawn her basket, resting it against a large stone). There's a terrible weight in that basket, there is.

JIM: That was a great send-off they gave the bridal pair.

MRS. MARKS: It was so. I wasn't on the wharf on account of my bad knee, but I seen from above, an' I met some of them now. I'm glad she had it fine, the poor young thing.

JIM: What "poor" is on her? Isn't it the day of her life?

MRS. MARKS: You could never tell that. It might. They say he wanted the money. They say it was signed and settled before ever he seen her. Well, she'll have her red carpet and all her fine show for her poor heart to feed on. That's the way.

PETER (coming from the door): Fine day, ma'am. 
MRS. MARKS: It is indeed, thanks be to God. 'Tis a day of the earth and the sky.

JIM: With the whole month of April floatin' around.

MRS. MARKS: Annie was tellin' me the bride looked like a queen.

PETER: Did you see Annie? She didn't bring me my dinner.

MRS. MARKS: Oh, look at that now! a shame and a sin! She's off across the field with that Roddy Mann.

JIM (jumps up): I'll go call her.

PETER: Stop where you are! (He strides off).

JIM (to MRS MARKS): You had a right to keep that to yourself.

MRS. MARKS: To leave her father without his bit! An' she romancin' around!

JIM: He'll have her life.

MRS. MARKS: She earns what she gets. Why don't she settle down? She's a bold wild thing.

JIM: He treats her cruel; it don't do her any good.

MRS. MARKS: And what would do her good? That Annie Kinsella will be -romancin' all her life with whoever she can.

JIM: The way he treats her — it only drives her on worse.

MRS. MARKS: You're too soft-hearted, Jimmy Harris. But I have a great wish for you, for the sake of your mother, God rest her soul. You'd he better to give Annie up.

JIM: Give up my life, is it?

MRS. MARKS: You have two good sisters, can't you settle with them, or get a sensible girl. I'm telling you now - that one - her head is full of folly and her heart is full of wile. She'd do you no good.

JIM: You have a lot of old talk. (Silence. Then distant cheering). They're not done with it yet.

MRS. MARKS: I was thinking of my marriage day when I was looking at them two. It is a thought would sadden anyone.

JIM: How is that, Mrs. Marks?

MRS. MARKS: That's how it is; the truth is the best to be told in the end. 
JIM: Haven't you Bill and Mary, and the little place. You didn't fare bad.

MRS. MARKS: Bad. What have bad or good to do with it? That is outside of the question. For twenty years you're thinking of that day, an' for thirty years you're lookin' back at it. After that you don't mind - you haven't the feelin'- exceptin' maybe an odd day, like to-day. (She takes her basket. They hear someone coming. MRS.MARKS puts down her basket again, and waits, expectant). Annie ... and you may be sure she's not alone.

(ANNIE KINSELLA is seen in the doorway. She is about twenty. She wears a dark shawl, a red dress, black shoes and stockings - all very neat. Her hair is bright gold. With her is RODDY MANN, a big lounging figure, cap pulled low over his eyes).

ANNIE: Now, Roddy, don't come any further. (Low tone. MRS. MARKS listens, JIM moves a little farther from the doorway). Give me the tin. (RODDY hands a tin to her).

RODDY: What did you promise?

ANNIE: Wait first till I tell you how she looked. (Low, eager).

RODDY: You have told me already; you have talked of nothin' else.

ANNIE: She was like what you'd dream. I think I never seen anything so grand. She was like a livin' flame passin' down by us. She was dressed in flamin' red from, top to toe, and - (puts her hand to her breast — here she had a diamond clasp.

RODDY: And there you have your heart. Now give us a kiss. What did you promise? Leave down the tin.

(ANNIE puts the tin on the ground, slips her hands up about his neck and gives him a long kiss).

ANNIE: That will do now.

RODDY: You have my heart scalded. (He moves off. Annie takes up the tin, wipes her mouth on her sleeve, very thoroughly, turns to wave to Roddy. Comes in).

ANNIE: Jimmy, it was like heaven. She looked that lovely. The launch was all white, and the deck covered with flowers. They had a red carpet-

JIM: You're late with his dinner.

ANNIE: Late! (Alarmed). The whistle didn't go!

JIM: Ten minutes apast one.

ANNIE: He'll have my life! 
MRS. MARKS: An' small blame to him so! Without a bit or a sup! A man want his dinner. He's gone down to find you.

JIM: Why couldn't you come?

ANNIE: What misfortune came over me? I am at a loss for a word. What will I do now?

MRS. MARKS: Take it down to him, —run.

ANNIE: He'd kill me, he'd kill me dead. I think I'll stop here till he'll come.

JIM: Here he is now. (All look towards the doorway).

MRS. MARKS (Turns to JIM): Don't be drawn into it, you.'Twould be a mistake. Keep your eyes on the ground; 'tis the safest place. You won't see what's happening, and you won't lose your head.

PETER (coming in): Is she there? (Sees Annie). Ah-h!

ANNIE (nervous, almost perky): I'm a bit late with the dinner; 'tis because of the weddin' I didn't hear the whistle: I didn't know it had gone one.

(Leaves his dinner-tin on the ground, not too near him, and moves away).

PETER: Hand me that tin.

(ANNIE hands it, keeping as far as possible from him. PETER, hits out at her, ANNIE dodges and partly escapes, but cries out; JIM springs forward; MRS. MARKS catches JIM by the arm).

MRS. MARKS: 'Tis a terrible misfortune for any man to take the least iota interest in a girl like that. (This flow stops them all).

JIM (after a silence): What do you want here, Mrs. Marks?

MRS. MARKS: I wouldn't be in it at all but for the sake of your mother, - 'tis well she's in the grave.

PETER (to ANNIE): Go down there, you - (gestures towards the barrier at the left) - and rake up the few stones I have agen the wall,

(ANNIE hesitates, looks at her father, at JIM, at MRS. $M A R K S)$.

PETER: Do you hear what I'm saying?

ANNIE: I don't mind what'll happen I can take care of myself.

(Goes off, left, with a backward look at JIM. JIM would follow but for PETER's forbidding look. PETER goes over to where the coats have been left on the stones. Takes his stick from under the coats.) 
JIM: This is the best sheltered place for takin' your dinner. You can have the sack on top of them stones.

PETER: Mind yer business.

MRS. MARKS: Steady now, keep steady. Don't let us have anything happen!...

JIM (to PETER): You have your dinner now, can't you leave her alone.

PETER: Does she belong to you? (Pause). Do she? When she do you can talk. (Goes).

MRS. MARKS: Supposin' you were to get a blow instead of herself — what good would that be?' It might do you a grievous harm! Great cheer to see her standin' upright if yourself was lyin' low! I wouldn't stir up the embers in a man like that. (JIM walks away from her). Now I'll tell you this - though I know you won't listen - if you were a man at all you'd make her marry you.

JIM: An' how I do that?

MRS. MARKS: Ah, you're too soft-hearted for any woman. 'Tis the hard man wins, and right he should. (Confidential now). Annie Kinsella — when I met her down there - was tellin' me how grand the bride looked. "She was dressed," said she, "in shimmerin' green from head to foot."

JIM: What's wrong with that?

MRS. MARKS: Didn't, you hear her now to Roddy Mann, "she was dressed in flamin' red from top to toe."

JIM: So she did.

MRS. MARKS: That's the count she puts' on the truth! I'm only tellin' you now so's you'll harden your heart! Whatever'll come easy is what she'll say. Now - for the sake of your mother - if you marry that girl, don't believe one word she'll tell you. That's the only way you'll have peace of mind! (A cry. JIM starts forward: MRS.MARKS catches his arm). Be a man now! Be a man, and don't get yourself hurt!

JIM: Keep out of my way!

(Tries to push her aside. ANNIE, a little dishevelled, frightened, and with her shawl trailing, runs on. She runs to the barrier at the right side, leans against it, and moans, nursing her shoulder).

MRS. MARKS (to JIM): Now strengthen your heart: quiet your mind. Don't do yourself harm on anyone's account. We get what we merit, and God is good. (Pause). I'll leave ye now. (Takes her basket, does not notice that she has left a small parcel on the stone: moves off. Near the barrier she stops again, looks back at JIM.) Don't be moved to any foolish compassion. The hard man wins. 
(Goes. JIM comes a little forward: sits down on an old plank, his back to ANNIE: takes a small notebook from his pocket, turns the pages; glances over his shoulder in ANNIE'S direction, slips the notebook into his pocket again: waits for ANNIE to come to him. After a moment she brushes aside her tears, comes over and sits down close beside him.)

ANNIE: It was a grand sight Jim, it was like heaven.

JIM (catches her wrist): He hurt you then, —did he do you any harm?

ANNIE: Ah, leave that now! Let us leave that behind us... The band, was playing, and the flags were grand-

JIM: 'Tis a shame you'd madden him. He'll harm you some day, and all your own fault. You won't have any life left. An' what can I do?

ANNIE: Didn't you see the launch at all?

JIM: I saw well from above.

ANNIE: You should have been on the wharf. The cheering an' the music, an' all the sun on the river, an' everyone happy-

JIM: We'd be all happy if you'd have sense.

ANNIE: She looked lovely passin' along, her hand restin' in his, and her body swayin' beside him down the path. The arms of the two families were painted on the launch: the sun was shinin' on it: everything was white or burnin' red, but she was dressed in pale pale gold and - (hands to breast) - two red flowers were crushed agen her here.

JIM (springs up): What lies are you tellin'? I saw her myself: she was dressed in grey: she had no flowers.

ANNIE (gentle, bewildered): Jimmy, what's wrong with you?

JIM: She was dressed in grey. Tell the truth!

ANNIE: It was in pale gold I saw her.

JIM (furious): And in shimmerin' green, an' in flamin' red, an' in milk white when it will suit you!

(Silence)

ANNIE (gets up slowly): You are a pack of blind owls — all the lot of you! I saw what I saw!

JIM: But why won't you tell the truth, — an' it just as easy?

(Turns from him)

ANNIE: Stop your fool talk! The truth! Burstin' in where you

Don't know. Oh, if I could have love! 
JIM: Will you leave talkin' of love when I'm tired of askin' you'd come to the priest with me! Are we to be married ever? Are we?

ANNIE (quietly): Whisht, Jimmy, whisht.

(Looks off away to the right, in the direction of the river.)

JIM: Are we? I must know.

ANNIE (to herself):

'Then the wet windin' roads,

Brown bogs and black water,

And my thoughts on white ships

And the King of Spain's daughter.'

JIM: I'm sick of that thing! Who's the King of Spain's daughter?

ANNIE: Myself.

JIM: Yourself . . . (A laugh.) And the bride beyond!

ANNIE: It is myself I seen in her — sailin' out into the sun, and to adventure.

JIM: Are you going to marry me? Make up your, mind.

(They hear a sound as of someone coming.)

ANNIE: What's that? (Frightened.) Is he coming? Jim, he says he'll make me sign on for the factory.

JIM: The factory? in the town beyond? (She nods.) That you couldn't stand before?

ANNIE: I was there six months: it would be five years this time.

JIM: Five years! you couldn't do that!

ANNIE: They're re only takin' them will be bound for five years. I couldn't face it. (Falters.) Every mornin' walkin' the road, every evenin' draggin' back so tired. He has the card: he's coming to make me, sign my name now.

JIM: It was a pity you didn't bring his dinner in time!

ANNIE: It was a great misfortune for me I am at a loss to explain it.

JIM: And I think he knew that Roddy was with you.

ANNIE: It is that decided him.

JIM: Why do you go with Roddy, and Jack? 
ANNIE: It is very unfortunate that I do! ... I would face any life — no matter what — before I'd go back to that place.

JIM: Did you kiss Roddy Mann again to-day?

ANNIE (injured): And who else was there for me to kiss?

JIM: When I left you last night did you go back to Jack Bolger?

ANNIE: Last night . . . no, I don't think I did last night.

JIM (furious): We're all the wan! You have no heart.

ANNIE: So must I go to the factory? Won't you marry me now?

JIM: Annie! — won't I. You know well — (Overjoyed, but checks himself.) Will you come with me to-night and we'll tell the priest?

ANNIE: Is it stand beside you an' you sayin' that? (Insulted) The ground would open under me! Go tell him yourself, let you.

JIM: Would you go back on me then?

ANNIE: I would not.

JIM: You would not? You've changed your mind often.

ANNIE: I'll be in the chapel the day he'll name.

JIM: You will? and come with me then?

ANNIE: What else is there for me?

JIM: Annie! — (checks himself) — I'll tell them look out for a place so: they can get a room in the town.

ANNIE: Tell who?

JIM: Molly and Dot. 'Tis I have the house: they knew they'd have to go.

ANNIE: Well then, they needn't. Let them stop where they are. What would I do without a woman to talk to?

JIM: I want you to myself.

ANNIE: I never heard the like! A good “man” he'd make to begin by turnin' his two sisters on the road! And they after mindin' the place since his mother died. 
JIM: Will you go back on me so?

ANNIE: Leave Molly and Dot stay where they are.

JIM: I will not.

ANNIE: What great harm would they do?

JIM: They'd be in it - spoilin' the world.

ANNIE: Spoilin' the world! I think you're crazy.

JIM: When we shut the house door I'll have no one in it but you and me.

ANNIE (after a moment): I think I'll stop with my father.

JIM: And go to the factory?

ANNIE: Maybe I wouldn't do either,- - but run away.

JIM: He'd go after you: he'd have you crippled.

ANNIE: I haven't signed yet. I might get on the soft side of him yet if I'd promise-

JIM: What promise would you keep? (Silence.) I have twenty pounds saved.

ANNIE: Where did you get that?

(Not greatly interested. Jim lakes out his notebook, opens it.)

JIM: Four years ago you said I had no money. I have the house now and besides what I earn I put by two shillin's every week.

ANNIE: Two shillin's ... you did! every week ... since that time long ago?

JIM (turning the pages of his notebook): A hundred shillings.... that was five pounds the first year ... and another five then ... and another ... and this is the fourth...

ANNIE (awed): You kept it up all that time?

JIM: Did you think I'd fall tired?

ANNIE: Let me see. I didn't know you were doin' that. (Takes the notebook, turns the pages. Silence - then-) Oh, 'tis smudged and dirty. Why couldn't you keep it clean? (Angered: throws the book from her. Silence.)

JIM: Two hundred weeks, and that's all 'you'd care. 
ANNIE: What would you do with it?

JIM (coming a little way back to her): It would set us up. . . To buy a few things. I'd have to give the priest some. Then whatever you'd like for the house, and yourself, so's we could settle down right.

ANNIE: Settle down. (A knell to her.) I dunno could I ever get into service in a place in London?

JIM (in fury): If your father heard you were at the crossroad last night — or if the priest heard tell of it - dancin' on the board, an' restin' in the ditch with your cheek agen mine and your body pressed to me.

ANNIE: It is only in the dark I could do it — for when I'd see the kind you are-

JIM (catches her): What's wrong with me now?

ANNIE (holding back): Is it me to go near you -me?

JIM (crushing her to him): What's wrong with me?

ANNIE: Jimmy! He's coming! Let go, let me go! Oh-h!

PETER (coming on): So that's what you're at! (ANNIE tries to escape. JIM holds her.) Stop there, stop there the two of you! You can let her go now. (To JIM. JIM releases ANNIE. She stands motionless.) Was she teasin' you?

JIM: She was.

PETER: Tauntin' you like?

JIM: She was.

PETER: I know . . . leadin' you on?

JIM: That's it.

PETER: Well, me fine lady, we'll put a stop to your fun. You can do some work now. Stay where you are! Stay there the two of you. (Goes to where the coats have been left, takes a card and a pencil from his coat pocket. Comes over to ANNIE) Write your name there. (ANNIE looks at Jim: he avoids her look.) Do you hear what I say? Write your name. We'll have no more cajolin'.

(ANNIE writes her name on the card. PETER taking back the card, hits at her. JIM knocks aside PETER'S blow: they face each other angrily.)

JIM: Can't you stop that! 
PETER: Oh you'd like to be standin' up for her, but you have no right! No more than to be kissin' her like you were now. She don't want you. You can go your road. (Wheels round on ANNIE.) Will you marry him now, or go to the factory? Five years there or your life with him?

JIM: I'm not askin' you, Annie, I wouldn't have it like that.

PETER: He’s backin' out now.

ANNIE (to Jim): I might as well have you. (Low) Who would I ever meet would be fit for me? Where would I ever find a way out of here?

PETER: Have you settled it so?

JIM: We have.

PETER: You'll take her like that?

JIM: I will.

PETER: Well, I'll keep the card, fearin' she'd change.

(Puts the card in his pocket. Goes off.)

ANNIE (softly): You have me ruined. It is all over now. You can go settle with the priest.

JIM: You won't ever regret it. You won't (But she turns away.)

ANNIE: Go on after him now.

(JIM hesitates: goes. ANNIE moves over to the barrier, looks

off away to the right. MRS. MARKS comes to the barrier at the left side, shades her eyes, looking on the ground for her parcel.)

MRS. MARKS: Well, - look where I left it. (Comes on, takes the parcel she had forgotten.) Well and indeed! my head will never spare my heels! Searchin' high and low. (Sees JIM'S notebook on the ground.) What is that there?

ANNIE: That belongs to Jim Harris. (Takes the book.) Jim Harris and myself are to be married very soon.

MRS. MARKS: What?! Is he going to marry you in face of all? Well, well, you might talk your head off, or you might spare your breath — it don't make any difference!

ANNIE: Maybe I won't mind it as much as I think.

MRS. MARKS: Be a good wife to him now. Don't give him the bad time you gave your poor father. Often I felt for that poor man when he wouldn't know where you'd be. (More kindly) You have no wish for it? (ANNIE shakes her head.) And there's many a girl would be boundin' with joy. Is there any other you'd liefer have? (ANNIE shakes her 
head.) Well now, well, you'll be all right. A good sensible boy. And you'll have a nice little place. Mind you keep it well, - that'll give you somethin' to do. You won't feel the days slippin'. (ANNIE moves restlessly away from her.) Well, well if you could get to care for him that would be a blessin' from God. It might come to you later. Sometimes it do, and more times it don't. It might come with the child.

ANNIE: I dread that.

MRS. MARKS: What's that you said?! Fie on you, then! Did you think you needn't suffer like the rest of the world? Did you think you were put here to walk plain and easy through the gate of heaven?

ANNIE: I dread it ... dread it.

MRS. MARKS: Would you ask to get in on what others would suffer?

ANNIE (to herself): I couldn't bear I'd be no more than any other wife. (Distant cheering is heard: ANNIE listens, looks away towards the river, - she flashes-) It won't be all they'll say of me: "She married Jimmy Harris."

MRS. MARKS: And what better could they say? You have a right to be grateful. Oh, you're a wild creature!

(But ANNIE is not listening: she has opened JIM'S notebook: studies it).

ANNIE (turning the pages): June. . . July . . October . . . November. . . December . . .

MRS. MARKS: Poor Jimmy Harris . . . I hope he's doin' a wise thing.

ANNIE: February, March, April . . June, July, August . . October — and I was black out with him then — November, December, April, June ... August-

MRS. MARKS: A good, sensible boy.

ANNIE: Boy! (She laughs exultantly) I think he is a man might cut your throat!

MRS. MARKS: God save us all!

ANNIE: He put by two shillin's every week for two hundred weeks. I think he is a man that — supposin' he was jealous — might cut your throat. (Quiet, —exultant, she goes)

MRS. MARKS: The Lord preserve us! that she'd find joy in such a thought!

\section{CURTAIN}


La Hija del Rey de España

POR

TERESA DEEVY

La Hija del Rey de España se estrenó por primera vez el 29 de Abril de 1935 en el Teatro Abbey de Dublín, con el siguiente reparto:

PETER KINSELLA

JIM HARRIS

MRS MARKS

ANNIE KINSELLA

RODDY MANN
JOHN STEPHENSON

CYRIL CUSACK

ANN CLEARY

RIA MOONEY

J.WINTER

La obra fue producida por Fred Johnson

Esta transcripción se ha hecho a partir del manuscrito PP-6-97 que está guardado en el Archivo de Teresa Deevy en la Universidad de Maynooth.

La Hija del Rey de España

Una obra de un solo acto.

Personajes:

Peter Kinsella

Jim Harris

Sra. Marks

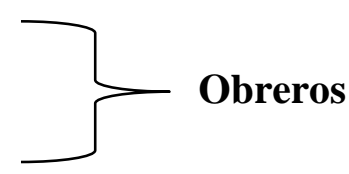

Una vecina

Annie Kinsella

La hija de Peter

Roddy Mann

Un holgazán

La acción de la obra se sitúa en una carretera cubierta de hierba en Irlanda durante la hora de la comida en un día de abril. 


\section{La Hija del Rey de España}

ESCENA: Un espacio abierto en una carretera con hierba. En cada lado de la carretera, barreras con señales de "Prohibido el tráfico" y "Carretera cortada". En la parte trasera una vieja pared dilapidada; una puerta pequeña en el centro de la pared permanece abierta y a través de la cual se pueden ver los campos. Unos trabajadores municipales han estado trabajando aquí. Dos abrigos, un termo, un saco viejo y un sombrero de caballero y un bastón están apilados en un montón de piedras cerca de una de las barreras. PETER KINSELLA, un hombre corpulento de cincuenta años, entra por el umbral. Lleva una piqueta, su mono de trabajo y sus botas están cubiertos de un polvo fino. Está en el centro, mira hacia la izquierda, entrecerrando sus ojos y luego hacia la derecha. JIM HARRIS llega silbando. Tiene veinticuatro años, lleva una gorra y un mono de trabajo polvoriento. Deja su pala contra la pared, va a la barrera del lado derecho y se apoya en ella, mirando hacia la derecha.

JIM: Magnífico trabajo en la boda de ahí abajo. La señorita como se llame se va a casar. Las mujeres se reunieron en el muelle con una hora y media de antelación para despedirse. (Se ríe. PETER asiente sin interés). Bien que se veía desde arriba, con la chalupa de blanco, y las banderas ondeando y el reflejo del sol en el agua. Valiente y alegre al principio pase lo que pase. (Toma su termo). ¡Venga hombre! Con el ruido de las sirenas no oí el silbato y seguí trabajando cinco minutos de más. ¿Crees que eso está bien?

PETER: Ella se está retrasando con mi comida.

JIM (consternado): ¿Qué? ¿En serio que no ha venido todavía?

PETER: No, no ha venido. Tarde, — por segunda vez en lo que va de semana.

JIM: Es por esa boda. Subirá ahora. Las mujeres no sienten el paso del tiempo ni el tiempo que hace cuando están esperando a una novia.

PETER: Se va a enterar... su padre sin comer.

JIM (mirando a la derecha): ¿Está en el muelle? ¿O en la orilla opuesta del río observando el comienzo?

PETER: ¿Sabré yo alguna vez, o cualquier otra persona, dónde esté Annie? Tú solo tienes hermanas, pero probablemente piensen más en ti que mi hija en mí. Oh, ya lo lamentará.

JIM: Es por el día que es; las mujeres no pueden pensar en otra cosa; son todas iguales. Molly y Dot estaban despiertas al amanecer- ¡Ojala sea un buen día! Cualquiera pensaría que estaban invitadas. Conocen a la novia de vista así que se van a meter en el gentío y van a echar un vistazo a ver qué tal está.

PETER: Si yo supiera dónde encontrar a Annie.

JIM: Annie estará aquí enseguida. Están saliendo del muelle — aunque no puedo distinguirla. 
PETER: ¿Y cómo lo harías? Lo más probable es que se haya ido con Roddy Mann. Flirteando con tipos como él - eso es lo único para lo que sirve - o con cualquier otro chico que ella pueda conseguir.

JIM: Si ella es así es porque necesita hacerlo; es su forma de ser, no puede remediarlo.

PETER: ¡Ya le ayudaré a remediarlo! Tú no tienes mucha prisa por estar con ella.

JIM (dando una vuelta en torno a él): ¡Sabes que no puedo esperar!

PETER: ¿Por qué no te casas con ella entonces? ¿Y evitas sus andaduras? Pareces no tener prisa.

JIM: Eso es lo que quiero, y lo sabes. ¿Cómo puedo obligarla?

PETER: Ay ¿Cómo? Si yo lo supiera (Se ríe despectivamente). Ah, eres demasiado joven.

(Va a la puerta, se queda allí mirando a los campos. JIM se sienta en las piedras y empieza a comer. La señora Marks, una mujer grande de unos cincuenta y cinco o así, que lleva un chal y una cesta en el brazo, llega a la barrera de la derecha. Empuja la barrera un poco a un lado y se acerca).

SRA. MARKS: ¿Puedo pasar por aquí? Sería un atajo.

JIM: ¿Es usted un automóvil señora? (le mira de arriba abajo). No lo parece, tiene usted estas dos piernas de ahí debajo. Entonces puede pasar, y bienvenida sea.

SRA. MARKS: Pensé que tenías más sentido común, Jim Harris. (Baja su cesta, dejándola apoyada en una piedra grande). Esa cesta pesa muchísimo, vaya si pesa.

JIM: Fue una gran despedida la que le dieron a los novios.

SRA. MARKS: Sí que lo fue. No estuve en el muelle por culpa de mi rodilla mala, pero lo vi desde arriba, y me encontré con algunos de ellos. Me alegra que todo le fuera bien a la pobrecilla.

JIM: ¿Qué tiene ella de pobre? ¿No es acaso este el mejor día de su vida?

SRA. MARKS: Eso nunca se puede decir. Puede ser. La gente dice que él iba por el dinero. Se dice que estaba todo firmado y apalabrado incluso antes de que él la viera. Bueno, así que tendrá la alfombra roja y todo ese espectáculo hermoso para que su pobre corazón se contente. Así son las cosas.

PETER (viniendo de la puerta): Buen día señora.

SRA. MARKS: De hecho lo es, gracias a Dios. Es un día terrenal y celestial.

JIM: Con el mes entero de Abril para disfrutarlo.

SRA. MARKS: Annie me estaba diciendo que la novia parecía una reina. 
PETER: ¿Vio usted a Annie? No me trajo la comida.

SRA. MARKS: Oh, ¡vaya! ¡Menuda vergüenza y un pecado! Allí está al otro lado del prado con ese Roddy Mann.

JIM (saltando): ¿Qué me dices? Voy a llamarla.

PETER: ¡Detente donde estás! (Se marcha).

JIM (a la Sra. Marks): Se lo podía haber guardado para usted.

SRA. MARKS: ¡Dejar a su padre sin bocado! Y ella de aventuras amorosas.

JIM: La va a matar.

SRA. MARKS: Tiene lo que se merece. ¿Por qué no sienta la cabeza? Es una chica desenfrenada y descarada.

JIM: Él la trata cruelmente. Eso no le hace ningún bien.

SRA. MARKS: ¿Y qué es lo que le haría bien? Esa Annie Kinsella estará tonteando toda su vida con quienquiera que pueda hacerlo.

JIM: La forma como él la trata — la hace ser peor.

SRA. MARKS: Tienes un corazón demasiado blando Jimmy Harris. Pero de verdad que te deseo una cosa, por el alma de tu madre, que Dios la bendiga. Ojala que renuncies a Annie.

JIM: Renunciar a mi vida, ¿Es eso?

SRA. MARKS: Tienes dos buenas hermanas, ¿No te puedes quedar a vivir con ellas, o conseguir a una mujer sensata? Te lo digo de verdad — esa chica — tiene la cabeza llena de pájaros y su corazón lleno de engaños. Ella no te haría ningún bien.

JIM: Habla como una vieja. (Silencio. A continuación ovaciones). Todavía no han terminado con la celebración.

SRA. MARKS: Estaba pensando en mi boda cuando miraba a esos dos. Es un pensamiento que llenaría de tristeza a cualquiera.

JIM: ¿Cómo es eso Sra. Marks?

SRA. MARKS: Así son las cosas. Lo mejor es decir la verdad al final.

JIM: ¿Acaso no tiene usted a Bill y Mary, y la casita pequeña? No le ha ido mal del todo.

SRA. MARKS: Mal. ¿Qué tiene que ver mal o bien con todo esto? Eso no viene al caso. Durante veinte años piensas en ese día, y durante treinta años estas recordándolo. 
Después de esto ya te da igual — no sientes lo mismo - excepto quizás durante un día casual, como hoy. (Toma su cesta. Oyen a alguien que viene. La Sra. Marks vuelve a dejar la cesta, y espera con expectación). Es Annie... y estate por seguro que no está sola.

(ANNIE KINSELLA surge en el umbral. -Tiene alrededor de veinte años. Lleva un chal oscuro, un vestido rojo, zapatos negros y medias- todo muy aseado. Su pelo es rubio vivo. Con ella esta Roddy Mann, un tipo grande y gandul, con su gorra ajustada sobre los ojos).

ANNIE: Ya vale Roddy, no te acerques más. (Con un susurro. La Sra. MARKS escucha, JIM se aleja del umbral). Dame la fiambrera. (Roddy le da la fiambrera).

RODDY: ¿Qué me prometiste?

ANNIE: Espera, primero te digo como iba la novia. (Despacito, ansiosa).

RODDY: Ya me lo has dicho; no has hablado de otra cosa.

ANNIE: Ella era como lo que una soñaría. Creo que nunca he visto nada tan grandioso. Era como una llama viva pasando junto a nosotros. Iba vestida de un rojo ardiente, de la cabeza a los pies, y (poniendo su mano en su pecho) - aquí llevaba un broche de diamantes.

RODDY: Y ahí tienes tu corazón. Venga dame un beso. ¿Qué me prometiste? Deja la fiambrera en el suelo.

(ANNIE pone la fiambrera en el suelo, desliza sus manos alrededor del cuello de Roddy y le da un largo beso).

ANNIE: Eso bastará por ahora.

RODDY: Me has escaldado el corazón. (Él se marcha. Annie recoge la fiambrera, se limpia la boca con la manga, meticulosamente, se da la vuelta para decirle adiós a Roddy con la mano. Entra dentro).

ANNIE: Jimmy, era como el paraíso. La novia estaba radiante. La chalupa era toda blanca, y el muelle estaba cubierto de flores. Tenían una alfombra roja -

JIM: Vienes tarde con su comida.

ANNIE: ¡Tarde! (Alarmada). ¡El silbato no sonó!

JIM: A la una y diez.

ANNIE: ¡Me va a matar!

SRA. MARKS: ¡Poca culpa le podrás echar! ¡Sin un pedazo de pan o algo de beber! Lo que un hombre quiere es su comida. Ha bajado a buscarte. 
JIM: ¿Por qué no pudiste venir?

ANNIE: ¿Cómo es que me ha pasado esta desgracia? No puedo ni decir palabra. ¿Qué voy a hacer ahora?

SRA. MARKS: ¡Bájale la comida corre!

ANNIE: Me va a matar y rematar. Creo que voy a quedarme aquí hasta que vuelva.

JIM: Él ya está aquí. (Todos miran hacia el portal).

SRA. MARKS: (Se gira hacia JIM): No te metas donde no te llaman. Sería un error. Mira al suelo, es lo más seguro. No verás lo que está pasando, y no perderás la cabeza.

PETER (entrando): ¿Esta ahí? (Ve a Annie). ¡Ah-h!

ANNIE (nerviosa, casi riendo): He llegado un poquito tarde con la comida; debido a la boda no oí el silbato: no sabía que había sonado.

(Deja la fiambrera de su comida en el suelo, no demasiado cerca de él, y se retira)

PETER: Pásame esa fiambrera.

(ANNIE se la pasa, manteniéndose lo más lejos posible de él. PETER, le intenta pegar, ANNIE le esquiva y escapa por poco, pero grita; JIM salta hacia adelante; la SRA. MARKS agarra a JIM por el brazo).

SRA. MARKS: Qué infortunio terrible para cualquier hombre mostrar cualquier interés hacia una chica como esa. (Este súbito comentario hace que todos se detengan).

JIM (después de un momento de silencio): ¿Qué es lo que busca aquí, Sra. Marks?

SRA. MARKS: Yo no me metería en esto si no fuera por el bien de tu madre, - tiene suerte de estar en la tumba.

PETER (se dirige a ANNIE): Baja allí, tú (gesticulando hacia la barrera de la izquierda) y recoge las pocas piedras que tengo contra la pared,

(ANNIE duda, mira a su padre, a JIM, a la Sra. MARKS).

PETER: ¿No oyes lo que estoy diciendo?

ANNIE: No me importa lo que pase, puedo cuidar de mi misma.

(Sale y se va, mirando de reojo a JIM. JIM la hubiera seguido a no ser por la mirada prohibitiva de PETER. PETER se nueve hacia donde los abrigos reposan sobre las piedras y coge su bastón de debajo de los abrigos). 
JIM: Este es el lugar más resguardado para comer el almuerzo. Puedes poner el saco encima de esas piedras.

PETER: No te metas donde no te llaman.

SRA. MARKS: Tranquilos todos, mantened la calma. Que no pase nada malo.

JIM (dirigiéndose a PETER): Ya tienes la comida, ¿No la puedes dejar en paz?

PETER: ¿Ella es tuya? (Pausa) ¿Te pertenece? Cuando así sea entonces podrás hablar. (Se $v a)$.

SRA. MARKS: Suponiendo que fueras tú el que recibiera el golpe en lugar de ella- ¿De qué serviría eso? ¡Te iba a doler mucho! ¡Qué bonito sería verla de pie estando tú en el suelo! Yo no le avivaría las brasas a un hombre tan caliente como él. (JIM empieza a andar alejándose de ella). Ahora te voy a decir algo — aunque sé que no me escucharás - si fueras un hombre de verdad la harías casarse contigo.

JIM: ¿Y cómo lo hago?

SRA. MARKS: Ah, tienes el corazón demasiado blando para las mujeres. Es el hombre duro el que gana, y así debe ser. (Confidencialmente ahora). Annie Kinsella — cuando me la encontré allá abajo - me estuvo diciendo lo maravillosa que estaba la novia. "Iba vestida" dijo, "de un verde reluciente de la cabeza a los pies".

JIM: ¿Qué tiene eso de malo?

SRA. MARKS: ¿No la has oído hablar ahora con Roddy Mann?, "iba vestida de un rojo llameante de la cabeza a los pies".

JIM: Así fue.

SRA. MARKS: ¡Ese es el caso que le hace a la verdad! ¡Solo te lo estoy diciendo para que endurezcas el corazón! Ella dirá lo primero que le venga a la mente, lo más fácil. Venga - por tu madre - si te casas con esa chica, no creas ni una palabra que te diga. ¡Esa es la única forma en la que tendrás la conciencia tranquila! (Un grito. JIM se abalanza hacia delante: La Sra. MARKS le sujeta del brazo). ¡Compórtate como un hombre ahora! ¡Se un hombre y que no te hagan daño!

JIM: ¡Quítese de en medio!

(Intenta empujarla a un lado. ANNIE un poco desarreglada, asustada, y con el chal medio colgando, entra corriendo. Corre hacia la barrera de la derecha, se apoya en ella, y gime mientras se toca el hombro).

SRA. MARKS (A JIM): Ahora a endurecer tu corazón: Tranquiliza tu mente. No te hagas daño por defender a nadie. Tenemos lo que nos merecemos, y Dios es misericordioso. (Pausa). Ya os dejo. (Toma su cesta sin notar que ha dejado un pequeño paquete sobre una piedra y se va. Cerca de la barrera se vuelve a parar y mira atrás a JIM.) No te dejes convencer por una estúpida compasión. El hombre duro es el que gana. 
(Se va. JIM se mueve un poco hacia delante y se sienta en una vieja tabla con la espalda dando a ANNIE; toma un pequeño cuaderno de su bolsillo y pasa las páginas; mira de reojo sobre su hombro en dirección a ANNIE y vuelve a guardar el cuadernillo en su bolsillo: espera a que ANNIE se acerque a él. Después de unos instantes ella se limpia las lágrimas, se acerca y se sienta junto a él.)

ANNIE: Qué vista más bonita Jim, era como el cielo.

JIM (agarra su muñeca): Te ha lastimado entonces, ¿Te ha hecho daño?

ANNIE: Ah, ¡Déjalo! Dejemos eso atrás... La banda tocaba, y las banderas eran preciosas-

JIM: Es una pena que le has puesto furioso. Algún día te va a hacer daño, y será todo por tu culpa. Te sentirás muerta por el resto de tu vida. ¿Y qué podré hacer yo?

ANNIE: ¿Llegaste a ver la chalupa?

JIM: La vi bien desde arriba.

ANNIE: Deberías de haber estado en el muelle. Con los vítores y la música, y el rio rebosante de sol, y todo el mundo contento-

JIM: Seríamos todos más felices si fueras más sensata.

ANNIE: La novia estaba radiante mientras pasaba, con su mano reposando en la del novio, y su cuerpo balanceándose junto al de él por el camino. Los escudos de armas de ambas familias estaban pintados en la chalupa. El sol estaba radiante: todo era blanco o de un rojo ardiente, pero ella iba vestida de color oro, muy muy claro y (poniendo las manos en su pecho) tenía dos flores rojas estampadas aquí, en el pecho.

JIM (incorporándose de un salto): ¿Qué mentiras dices? La vi con mis propios ojos: ella iba vestida de gris y no llevaba flores.

ANNIE (dulce, desconcertada): Jimmy, ¿Qué te pasa?

JIM: Ella iba vestida de gris. Di la verdad.

ANNIE: Iba de un oro claro, yo la vi.

JIM (furioso): ¡iY de un verde reluciente, y de un rojo llameante, y de blanco como la leche cuando te convenga!!

(Silencio)

ANNIE (se levanta lentamente): Sois todos un montón de búhos ciegos- ¡todos vosotros! ¡Yo vi lo que vi!

(Se aparta de él)

JIM: ¿Pero por qué no dices la verdad, — ¿No es igual de fácil? 
ANNIE: ¡Para de decir estupideces! ¡La verdad! Hablando de lo que no sabes. Oh ¡Si yo pudiera sentir el amor!

JIM: ¿Y que no dejes de hablar de amor cuando estoy harto de pedirte que vengas conmigo al cura? ¿Nos vamos a casar algún día? ¿De verdad?

ANNIE (en voz baja): Calla Jimmy, ssshhhhhh

(Mira en la distancia hacia la derecha, —en la dirección del río)

JIM: ¿Nos vamos a casar? Necesito saberlo.

ANNIE (a sí misma):

'Entonces los húmedos y sinuosos caminos,

Ciénagas marrones y agua negra,

Y mis pensamientos con barcos blancos

Y con la hija del Rey de España.'

JIM: ¡Estoy harto de eso! ¿Quién es la hija del Rey de España?

ANNIE: Yo misma.

JIM: Tu misma. . . (Se ríe.) ¡Y también la novia allí a lo lejos!

ANNIE: Me he visto yo misma en ella —navegando hacia el sol y hacia la aventura.

JIM: ¿Te vas a casar conmigo? Decídete.

(Oyen un ruido como de alguien que se acerca.)

ANNIE: ¿Qué pasa? (Asustada) ¿Es él el que se acerca? Jim, dice que me hará inscribirme para trabajar en la fábrica.

JIM: ¿La fábrica? ¿La del pueblo de al lado? (Ella asiente) ¿La que no podías aguantar la otra vez?

ANNIE: Estuve allí seis meses: hace ahora cinco años.

JIM: ¡Cinco años! ¡Pero si no podías con eso!

ANNIE: Están reclutando de momento con contratos para cinco años. No podría enfrentarme a eso. (Flaqueando) Cada mañana caminando por la carretera, cada tarde de vuelta arrastrándome por el cansancio. Lleva la tarjeta de empleo: viene para obligarme, para que firme ahora con mi nombre.

JIM: ¡Es una pena que no le trajeras la comida a tiempo!

ANNIE: Fue una gran desgracia para mí que no puedo explicar.

JIM: Y creo que sabe que Roddy estaba contigo. 
ANNIE: Eso es lo que le ha hecho tomar la decisión.

JIM: ¿Por qué sales con Roddy? ¿Y con Jack?

ANNIE: ¡Es la desgracia que tengo!. . . Aceptaría cualquier tipo de vida — no importa la que sea- antes que volver a ese lugar.

JIM: ¿Besaste a Roddy Mann hoy otra vez?

ANNIE (ofendida): ¿Y quién más estaba ahí para que yo le besara?

JIM: ¿Cuándo te dejé anoche, te fuiste luego con Jack Bolger?

ANNIE: ¿Anoche?... no, no creo que fuera anoche.

JIM (furioso): Todos somos iguales para ti. No tienes corazón.

ANNIE: Entonces, ¿Debo ir a la fábrica? ¿Ahora no te casarás conmigo?

JIM: ¡Annie! ¿Qué si me casaría contigo? Lo sabes bien - (Contentísimo, pero se contiene) ¿Vendrás conmigo esta noche y se lo decimos al cura?

ANNIE: ¿Para estar al lado tuyo y tú diciendo el qué? (Ofendida) ¡La tierra me tragaría! Ve y se lo dices tú mismo, te dejo.

JIM: ¿Te volverías contra mí entonces?

ANNIE: No lo haría.

JIM: ¿Seguro? Has cambiado de idea muchas veces.

ANNIE: Estaré en la capilla el día que él diga.

JIM: ¿Lo harás? ¿Y vendrás conmigo entonces?

ANNIE: ¿Qué otra opción me queda?

JIM: ¡Annie! — (Intentando asegurarse) - Les diré que busquen nuevo alojamiento: pueden conseguir una habitación en el pueblo.

ANNIE: ¿Decírselo a quién?

JIM: A Molly y a Dot. La casa es mía: ellas sabían que se tendrían que ir.

ANNIE: Bueno entonces, no tienen por qué irse. Déjalas que se queden dónde están. ¿Qué haría yo sin una mujer con la que hablar?

JIM: Te quiero para mí solo. 
ANNIE: ¡Nunca he oído nada igual! ¡Menudo buen "hombre” sería el que empieza echando a sus dos hermanas a la calle! ¡Y eso que ellas han cuidado de la casa desde que la madre murió!

JIM: ¿Vas a faltar a tu palabra?

ANNIE: Deja a Molly y a Dot quedarse donde están.

JIM: No lo haré.

ANNIE: ¿Pero qué daño causarían?

JIM: Estarían ahí arruinándonos la vida.

ANNIE: ¿Arruinándonos la vida? Creo que estás loco.

JIM: Cuando cerremos la puerta de la casa no habrá nadie allí excepto tú y yo.

ANNIE (después de un momento): Creo que me quedaré con mi padre.

JIM: ¿E ir a la fábrica?

ANNIE: Quizá no haga eso tampoco, sino que me escape de casa.

JIM: Te perseguirá y te acabará lisiando.

ANNIE: No he firmado todavía. Puede que le convenza y saque su lado cariñoso si le prometo...-

JIM: ¿Qué promesa cumplirías? (Silencio) Tengo veinte libras ahorradas.

ANNIE: ¿De dónde las has sacado?

(No muestra mucho interés. Jim saca su cuadernillo y lo abre).

JIM: Hace cuatro años dijiste que no tenía dinero. Ahora tengo la casa y además de lo que gano ahorro dos chelines cada semana.

ANNIE: Dos chelines. . ¿ ¿De verdad? todas las semanas. . ¿ desde esa vez hace tanto tiempo?

JIM (pasando las páginas de su cuadernillo): Cien chelines. . . eso eran cinco libras en el primer año. . y y otras cinco después. . . y otras más. . . y este es el cuarto..

ANNIE (asombrada): ¿Seguiste ahorrando todo ese tiempo?

JIM: ¿Pensabas que me rendiría? 
ANNIE: Vamos a ver. yo no sabía que estabas haciendo esto. (Toma el cuadernillo, pasa las páginas. Silencio - entonces-) Oh, esta emborronado y sucio. ¿Por qué no lo tienes más limpio? (Enfadada: Tira el cuadernillo lejos de ella. Silencio.)

JIM: Doscientas semanas, y eso es todo lo que te importa.

(Se aleja)

ANNIE: ¿Qué harías con este dinero?

JIM (retrocediendo un poco hacia ella): Nos permitiría empezar con buen pie. . Comprar unas pocas cosas. Tendría que darle algo al cura. Después lo que quieras para la casa, y para ti, de manera que podamos echar raíces bien echadas.

ANNIE: Echar raíces. (Sintiendo el principio del fin). No sé, ¿Quizás pudiera conseguir un trabajo de sirvienta en alguna casa en Londres?

JIM (enfurecido): Si tu padre supiera que estabas en el cruce de caminos anoche $-\mathrm{o}$ si al cura le llegaran noticias de ello- bailando en la tarima, y descansando en la zanja con tu mejilla contra la mía y tu cuerpo pegado al mío.

ANNIE: Solamente en la oscuridad podía hacerlo - porque entonces vería la clase de persona que eres-

JIM (agarrándola): ¿Qué tengo yo de malo ahora?

ANNIE (conteniéndose): ¿Soy yo la que se acerca a ti? ¿Yo?

JIM (estrujándola contra él): ¿Qué tengo de malo?

ANNIE: ¡Jimmy! ¡Que va a venir! ¡Déjame! ¡Déjame ir! ¡Ohhh!

PETER (entrando): ¡Así que eso es en lo que estás! (ANNIE trata de soltarse. JIM la sujeta.) ¡No os mováis, parad los dos! Ya puedes soltarla. (A JIM. JIM suelta a ANNIE. Ella permanece inmóvil) ¿Se estaba burlando de ti?

JIM: Sí, lo estaba haciendo.

PETER: ¿Como tomándote el pelo?

JIM: Sí, lo hacía.

PETER: Lo sé... ¿Provocándote?

JIM: Sí, eso es.

PETER: Bien, mi bella dama, vamos a poner fin a tu diversión. Ahora puedes trabajar un poco. ¡Quédate donde estás! ¡Quedaos ahí los dos! (Va a donde se han dejado los abrigos, toma una tarjeta y un lápiz del bolsillo de su abrigo. Se acerca a ANNIE) Escribe tu nombre ahí. (ANNIE mira a JIM: Él evita su mirada.) ¿Escuchas lo que digo? Escribe tu nombre. Ya basta de engatusamientos. 
(ANNIE escribe su nombre en la tarjeta. PETER tomando la tarjeta, le golpea. JIM intercepta y desvía a un lado el golpe de PETER: se miran con rabia.)

JIM: ¿La puedes dejar en paz?

PETER: Oh te gusta defenderla, ipero no tienes derecho! no más que estar besándola como lo estabas haciendo ahora. Ella no te quiere. Puedes seguir tu camino. (Gira en torno a ANNIE.) ¿Te casarás con él ahora, o irás a la fábrica? ¿Cinco años allí o a vivir con él?

JIM: Yo no te lo pido Annie, no lo haría de esa manera.

PETER: Ahora se está echando atrás.

ANNIE (a Jim): Para el caso prefiero tenerte a ti. (En voz baja) ¿Podré encontrar a alguien alguna vez que sea mi pareja ideal? ¿Dónde encontraría una salida a este lugar?

PETER: ¿Lo habéis acordado entonces?

JIM: Sí, lo hemos hecho.

PETER: ¿La aceptarás así?

JIM: Sí, lo haré.

PETER: Bueno, me quedaré con la tarjeta, por temor a que ella cambie de opinión. (Pone la tarjeta en su bolsillo. Se va.)

ANNIE (dulcemente): Me has arruinado la vida. Todo se ha acabado. Puedes ir para arreglarlo con el cura.

JIM: Nunca te arrepentirás de esto. No lo harás (pero ella se aleja).

ANNIE: Venga, ve a buscarlo.

(JIM duda y se va. ANNIE pasa la barrera, mira a lo lejos hacia la derecha. La SRA MARKS se acerca a la barrera desde la izquierda, cubriendo sus ojos, buscando su paquete por el suelo.)

SRA. MARKS: Vaya, - mira donde me lo dejé. (Se acerca, recoge el paquete que había olvidado). ¡Vaya que sí! ¡Quien no tiene cabeza debe tener piernas! buscando de arriba a abajo. (Ve el cuadernillo de JIM en el suelo). ¿Qué es eso que está ahí?

ANNIE: Eso pertenece a Jim Harris. (Toma el cuadernillo). Jim Harris y yo nos vamos a casar muy pronto.

SRA. MARKS: ¿Qué? ¿Se va a casar contigo a pesar de todo? Vaya, —vaya, puedes hablar por los codos, o puedes cerrar el pico- ¡No hay mucha diferencia!

ANNIE: Quizás no me importe tanto como pienso. 
SRA. MARKS: Sé una buena esposa para él. No le hagas sufrir como hiciste con tu pobre padre. A menudo lo sentía por ese pobre hombre cuando él no sabía dónde estabas. (Más amablemente) ¿No le deseas? (ANNIE niega con su cabeza) Hay muchas mujeres que estarían saltando de alegría. ¿Hay alguna otra a la que se lo dejarías tener? (ANNIE niega con su cabeza). Vale, bien, vas a estar bien. Un buen chico sensato. Y tú tendrás un hogarcito coqueto. Mantenlo así — de esta forma tendrás algo que hacer. No notarás los días que pasan. (ANNIE se aleja de ella nerviosa). Muy bien, si pudieras cuidar de él, eso sería una bendición divina. Es algo que quizás te ocurra más tarde. A veces pasa y muchas veces no. Puede que te ocurra cuando tengas un bebé.

ANNIE: Eso me da pavor.

SRA. MARKS: ¿Qué es eso que dices? ¡Debería darte vergüenza! ¿Te pensabas que tú no tenías necesidad de sufrir como el resto del mundo? ¿Te pensabas que naciste para pasar felizmente por la puerta del paraíso?

ANNIE: Me espanta. . . me aterroriza.

SRA. MARKS: ¿Preferirías evitar lo que hace sufrir a los demás?

ANNIE (hablando para sí misma): No podría soportar no ser más que cualquier otra esposa. (Se oyen ovaciones en la distancia: Annie escucha, mira a lo lejos hacia el río — se enfada). No será lo único que digan de mí: "Se casó con Jimmy Harris"

SRA. MARKS: ¿Y qué cosa mejor podrían decir? Tienes el derecho de ser agradecida. ¡Oh eres una fiera salvaje!

(Pero Annie no está escuchando: ha abierto el cuadernillo de Jim: lo revisa)

ANNIE:(Pasando las páginas): Junio . . Julio . . Octubre . . Noviembre . . . Diciembre . . .

SRA. MARKS: Pobre Jimmy Harris. .. espero que esté haciendo lo correcto.

ANNIE: Febrero, Marzo, Abril . . J Junio, Julio, Agosto . . Octubre - y yo no le aguantaba a él entonces — Noviembre, Diciembre, Abril, Junio . . . Agosto-

SRA. MARKS: Un chico bueno y sensato.

ANNIE: ¡Un chico! (Ella se ríe con júbilo) Creo que es un hombre capaz de degollarte.

SRA. MARKS: ¡Que Dios nos salve!

ANNIE: Ha estado ahorrando dos chelines por semana durante doscientas semanas. Creo que es un hombre que - suponiendo que tuviera celos - podría cortarle el cuello a una. (Con tranquilidad, exultante, se va)

SRA. MARKS: ¡Que el Señor nos proteja! ¡Y que encuentre placer en semejante idea! 
Andrés Romera is a lecturer at the Department of Languages, Tourism and Hospitality, Waterford Institute of Technology, Ireland. He specializes in language education, adult education and world literatures.

aromera@wit.ie 